ОРЛИНСКАЯ Ольга Михайловна - кандидат политических наук, доцент кафедры теории политики и коммуникации Нижегородского государственного университета им. Н.И. Лобачевского (603950, Россия, г. Нижний Новгород, ул. Ульянова, 2; orlinskaya@mail.ru)

\title{
РЕГИОНАЛЬНЫЕ ВЫБОРЫ В НИЖЕГОРОДСКОЙ ОБЛАСТИ В 2002 г.: ПРАВОВАЯ БАЗА, ПАРТИИ, ТЕХНОЛОГИИ И ИТОГИ
}

\begin{abstract}
Аннотация. В статье рассматриваются вопросы организации выборной кампании в Законодательное собрание Нижегородской области в 2002 г. Автор выявляет роль политических партий и особенности применения избирательных технологий, определяет наиболее значимые аспекты итогов выборов в Нижегородский региональный парламент в 2002 г.

Ключевые слова: выборы, Законодательное собрание, технологии, избирательный залог, партии
\end{abstract}

B настоящее время неоднократно утверждается, что в современной Российской Федерации недостаточно высока степень политической конкуренции. Особенно это касается региональных и местных выборов. Фавориты на них в большей части случаев известны заранее, а их поражение воспринимается не иначе, как сенсация.

Признаем, что менее двух десятилетий назад ситуация была иной, в т.ч. и на региональных выборах. Вполне подтверждается этот тезис выборной кампанией в Законодательное собрание Нижегородской области, завершившейся 31 марта 2002 г. Выборы в региональную легислатуру проводились на основе общефедерального законодательства, а также Положения о выборах в Законодательное собрание Нижегородской области, принятого в 1997 г. ${ }^{1}$ Крайне важно упомянуть о следующих обстоятельствах. Во-первых, вся область была разбита на 45 округов, каждый из которых делегировал в областную легислатуру 1 депутата, т.е. имела место мажоритарная система простого большинства. Во-вторых, 17 депутатов представляли областной центр, а 28 - районы области. В-третьих, выборы признавались недействительными либо по причине нарушений процедуры выборов, либо ввиду того, что большинство избирателей проголосовали против всех кандидатов, либо если в выборах приняли участие менее $25 \%$ избирателей, проживающих в избирательном округе. В-четвертых, федеральный закон «Об основных гарантиях избирательных прав граждан Российской Федерации» от 30 марта 1999 г. $^{2}$ предусматривал, что кандидатам в депутаты и объединениям впервые предоставлялся выбор - собирать подписи избирателей в поддержку своего выдвижения или же вносить избирательный залог [Босова 2005: 122]. В Нижегородской обл. сумма избирательного залога составляла 10 тыс. руб.

Важно отметить, что к началу марта 2002 г. уже были зарегистрированы 239 кандидатов, 3 сняты с дистанции, 149 зарегистрированы благодаря внесению избирательного залога ${ }^{3}$. Незадолго до окончания предвыборной кампании

\footnotetext{
1 Положение о выборах в Законодательное Собрание Нижегородской области. 1997. - Бюллетень Законодательного собрания Нижегородской области. № 4. С. 32-62.

2 Федеральный закон от 30.03.1999 № 55-Ф3. «О внесении изменений и дополнений в Федеральный закон "Об основных гарантиях избирательных прав и права на участие в референдуме граждан Российской Федерации”». - Российская газета. 1999. 6 апр. С. 2.

3 Смирнов С. 2002. Кто попадет в бюллетень? - Нижегородская правда. 5 марта. С. 1.
} 
имелись 276 кандидатов, причем 16 кандидатам было отказано ${ }^{1}$. Всего в период от старта предвыборной кампании в конце января до начала марта 2002 г. были выдвинуты 293 кандидата. Для сравнения: в прошлую выборную кампанию в областной парламент в 1998 г. их насчитывалось 228. Таким образом, сам факт выдвижения большего числа кандидатов говорил о том, что политическая активность в регионе в начале нулевых годов была выше, нежели в конце 1990$\mathrm{X}$.

Следует упомянуть, что наибольшее их число было зарегистрировано в округе № 34 (Княгининский, Пильнинский, Сергачский районы) - 12. Наиболее же распространенными показателями следует считать 5 (именно так обстояли дела в 12 округах) и 7 кандидатов (6 округов). По нашему мнению, именно такие показатели - 5-7 кандидатов в депутаты - следует считать оптимальными на выборах в региональный парламент.

Следующий крайне важный с нашей точки зрения аспект - активность политических партий в деле проведения данной выборной кампании (напомним, что федеральный закон № 95-Ф3 от 7 июля 2001 г. «О политических партиях», объективно содействовавший их усилению как политических акторов, действовал к тому времени меньше года). Как известно, важную роль практически во всех округах региона обещала сыграть Народная партия Российской Федерации (согласно высказыванию одного из лидеров НПРФ и по совместительству одного из наиболее известных нижегородских политиков В.В. Булавинова). Лишь в 3 округах эта организация не выдвинула своих кандидатов. Характерно также, что все 43 члена Народной партии РФ выдвигались именно своей партией, а не группой избирателей или же путем самовыдвижения. Что касается КПРФ, то ее кандидаты также баллотировались по 20 округам из 45. Во всех случаях, кроме одного, все члены КПРФ выдвигались не от лица своей партии, но от группы избирателей. Что же касается прочих политических партий, то либо их члены не стремились оглашать свою политическую принадлежность (нагляднейший пример тому - А.В. Санников, видный деятель СПС, избиравшийся по 44-му округу, в который входили Тонкинский, Уренский, Шарангский и часть Ветлужского района), либо же они изначально имели очень малые шансы на успех (исключением являлась партия СПС).

Не слишком активно проявило себя и местное отделение «Единой России». В самом деле, лишь двое кандидатов открыто афишировали свою принадлежность к этой влиятельной в стране политической силе. Даже членов «Яблока» оказалось и то больше - 3. По округу № 17 (Приокский район г. Нижнего Новгорода) баллотировался кандидат, выдвинутый мало известной широкой общественности партией «Миллион друзей», объединяющей любителей животных. Таким образом, уже сам процесс выдвижения кандидатов проиллюстрировал малую значимость политических партий в политических процессах на региональном уровне и показал правоту противников выборов в Законодательное собрание Нижегородской области на смешанной основе. Вообще же политические партии участвовали в этих выборах в тесном союзе с крупными финансовыми группами и далеко не всегда играли в этом процессе первую скрипку.

Активно использовалась в ходе выборной кампании 2002 г. технология выдвижения кандидатов-двойников. Она позволяла «оторвать» порой 5-7\% у неугодного кандидата. Выдвижение таковых имело место сразу в 4 округах (№ 12, 14, 35 и 37). В округе № 12 (Канавинский район г. Нижнего Новгорода) баллотировались двое Ермолаевых. В округе № 37 (Воротынский, Лысковский, Спасский районы) были зарегистрированы 2 кандидата по фамилии Бабушкин.

\footnotetext{
1 Новые «отказники». 2002. - Нижегородская правда. 30 марта. С. 2.
} 
Самая же интересная ситуация сложилась в округе № 35. Там в борьбе за мандат депутата, не считая россиянина с африканскими корнями, сошлись четверо Воробьевых (двое - самовыдвиженцы) и двое Бурдиковых, причем оба числились директорами. По нашему мнению, такое число двойников являлось отчасти и оборотной, негативной стороной возможности применения практики «избирательных залогов» [Устинкин, Полякова 2009: 9].

В целях усложнения ситуации некоторые кандидаты применяли такие технологии, как использование псевдонимов. Норма эта, кстати, законодательством разрешена. Так, для усложнения ситуации в округе № 12 одного из Ермолаевых по его просьбе именовали в скобках Настоящий, а другого - Нижфарм. По нашему мнению, кстати, именно Настоящий и был кандидатом-двойником ${ }^{1}$.

Разумеется, столкнувшись с «черным пиаром», участники предвыборной гонки начали жаловаться друг на друга в ЦИК, что, несомненно, могло привести к уменьшению числа кандидатов в депутаты. В основном фантазия при сочинении жалоб друг на друга замыкалась на поиске «двойников» и даже на обвинении конкурентов в рассылке писем со спорами сибирской язвы.

Кроме того, органы правопорядка задерживали тех, кто расклеивал «агитки» в не предназначенных для этого местах, а также распространителей сведений, порочащих того или иного кандидата в депутаты. «Если поработать, кое-кого можно снимать с выборов», - осторожно заметил в одном из интервью представитель ГУВД. Наиболее же заметный скандал разгорелся в округе № 16 (Советский район г. Нижнего Новгорода), где вечером 29 марта с дистанции по решению суда был снят с предвыборной гонки ее фаворит - известный нижегородский предприниматель А.А. Бочкарев. Ему инкриминировали подкуп избирателей. На его сторону встали практически все нижегородские депутаты Государственной думы, что, впрочем, никак не повлияло на решение суда.

Следует признать, что основная масса кандидатов использовала традиционные меры борьбы за избирателей. К избирателям они обращались через электронные и печатные СМИ (в т.ч. оплачивая спецвыпуски газет, например газеты «Нижегородский рабочий»), а также с помощью рекламных носителей (плакаты, листовки и т.п.). В основном декларировалось, что они живут той же жизнью, что и их избиратели. Интернет-ресурсы практически не использовались.

В целом уместно согласиться с нижегородским политологом, на тот момент доцентом НГПУ С.Н. Кочеровым, считавшим, что у населения к выборам нет интереса, и не только потому, что люди устали от них, но и потому, что мало кому из кандидатов удалось выйти с избирателями на разговор по существу тех проблем, которые действительно волнуют население. Ряд кандидатов активно высказывали обещания, которые никак не могли исполнить в статусе депутатов регионального парламента, поскольку они вели речь о пусть и злободневных, но все же проблемах общефедерального масштаба. Выборы в целом были скучные, потому что не было видно никаких оригинальных ходов, предложений, идей. Иногда даже складывалось такое впечатление, что кампания велась по инерции ${ }^{2}$.

В целом же выборы выиграли кандидаты, представлявшие крупные бизнесструктуры, а также органы местного самоуправления. В сельских округах позиции действующих глав - депутатов достаточно сильны. Намечалось несколько потрясающих по своей преемственности комбинаций ${ }^{3}$.

\footnotetext{
1 Нижегородский рабочий. 2002. Спецвыпуск. 7 марта. С. 1-2.

2 Кочеров С. 2002. У нас нет чиновников, отвечающих за явку избирателей. - Монитор. 25-31 марта. C. 16 .

3 Сухонина Ю. 2002. Последняя заря ОЗС. - Монитор. 21-27 янв. С. 5.
} 
Неожиданностью для многих стало успешное выступление на выборах представителей партии СПС. Представительство этой партии в целом увеличилось в областном законодательном органе в 2 раза [Пахомова 2013: 118]. Судя по всему, данное обстоятельство было связано с сильной связью лидеров СПС с Нижегородской областью [Дахин 2004: 40].

В целом нельзя не признать, что, с одной стороны, областное Законодательное собрание Нижегородской области, избранное в 2002 г., не стало законодателем политической моды в регионе и площадкой для озвучивания политических интересов, но являлось скорее клубом, члены которого отстаивали свои интересы, равно как и интересы стоящих за ними бизнес-структур ${ }^{1}$. При этом следует отметить, что последние могли не только выдвигать изначально «своих» кандидатов, но также и договориться на старте предвыборной кампании с «проходным» кандидатом и, по сути, во многом превратить его в «своего» ${ }^{2}$. Общее число представителей крупных коммерческих структур в Законодательном собрании Нижегородской области того созыва составило 30 чел. [Ефимова 2007: 24].

Нельзя также не признать, что административный ресурс на выборах 2002 г. использовался мало, поскольку губернатор Г.М. Ходырев принципиально отказался от того, чтобы проводить в региональный парламент «своих» людей ${ }^{3}$. Впрочем, попытки в ходе предвыборной кампании «прислониться» к губернатору, т.е. фактически использовать его бренд, имели место ${ }^{4}$. Отмечалось также, что уровень фальсификации был в начале нулевых годов низким - как правило, в регионе были сфальсифицированы не более $2 \%$ бюллетеней 5 .

В целом же признаем, что высокая конкурентность, малое использование административного ресурса и наличие политиков-либералов не делают автоматически орган законодательной власти по-настоящему эффективным ни в качестве структуры, принимающей значимые решения, ни в качестве трибуны для отстаивания интересов населения.

\section{Список литературы}

Босова Е.Н. 2005. Избирательное законодательство: проблемы систематизации: дис. ... к.ю.н. Уфа. 192 с.

Дахин А.В. 2004. Альтернативы регионального демократического транзита в контексте трансформаций элит региона. - Гуманитарий. № 4. С. 36-42.

Ефимова И.Н. 2007. Социологический анализ деятельности регионального парламента как актора социальной политики: автореф. дис. ... к.соц.н. Н. Новгород. $38 \mathrm{c.}$

Пахомова Е.А. 2013. О мифологизации политического сознания России и поражении либеральных сил в 2003 году. - Научное мнение. № 3. С. 117-120.

Устинкин С.В., Полякова Ю.С. 2009. Коммуникативная составляющая в позиционировании во власти региональных политических элит (на примере ряда регионов Приволжского федерального округа). - Власть. № 6. С. 8-11.

\footnotetext{
1 Макарычев А. 2002. От какого наследства мы отказываемся. - Нижегородский рабочий. 24 янв. С. 2.

2 Казаков М. 2002. Какими будут выборы в ОЗС? - Нижегородская правда. 12 янв. С. 2.

3 Кочеров С. 2002. В ожидании Законодательного собрания. - Нижегородский рабочий. 30 янв. С. 8.

4 Прислониться к губернатору. 2002. - Город и горожане. 26 марта - 1 апреля. С. 2.

5 Казаков М. 2002. Какими будут выборы в ОЗС? - Нижегородская правда. 12 янв. С. 2.
} 
ORLINSKAYA Olga Mikhailovna, Cand.Sci. (Pol.Sci.), Associate Professor of the Chair of Theory of Politics and Communication, Lobachevsky State University of Nizhny Novgorod (2 Ul'yanova St, Nizhny Novgorod, Russia, 603950; orlinskaya@mail.ru)

\section{REGIONAL ELECTIONS IN THE NIZHNY NOVGOROD REGION IN 2002: LEGAL FRAMEWORK, PARTIES, TECHNOLOGIES AND RESULTS}

Abstract. The article deals with the organization of the election campaign to the Legislative Assembly of the Nizhny Novgorod Region in 2002. The author reveals the role of political parties and peculiarities of application of electoral technologies and determines the most significant aspects of the results of the elections to the Nizhny Novgorod Regional Parliament in 2002. Keywords: elections, Legislative Assembly, technologies, electoral pledge, parties 